\title{
Aplikasi Pupuk Organik Cair NASA Terhadap Pertumbuhan dan Hasil Tanaman Bawang Merah (Allium cepa var. Agregatum L.) Varietas Lokal Wamena
}

\author{
Paul Wanimbo, Sumiyati Tuhuteru* \\ Program Studi Agroteknologi, Sekolah Tinggi Ilmu Pertanian Petra Baliem Wamena, \\ Jl. Sanger, Potikelek, Wamena, Jayawijaya, Papua 99511 \\ *Email: sumiyati.tuhuteru@yahoo.com
}

\begin{abstract}
Abstrak
Upaya untuk meningkatkan produksi tanaman bawang merah antara lain dengan perbaikan sistem budidaya misalnya penerapan pertanian organik berkelanjutan, seperti pemanfaatan pupuk organik cair. Salah satu pupuk organik cair yang diperdagangkan, yang siap diaplikasikan ke tanaman yaitu pupuk organik cair NASA. Penelitian ini bertujuan untuk mengetahui respon pertumbuhan dan hasil tanaman bawang merah varietas lokal Wamena dan untuk mengetahui konsentrasi pupuk organik cair yang efektif dalam budidaya tanaman bawang merah varietas lokal Wamena. Penelitian ini dilaksanakan pada bulan Juni - Agustus 2018 di lahan percobaan STIPER Petra Baliem Wamena kemudian dilanjutkan di Laboratorium Agroteknologi STIPER Petra Baliem Wamena. Perlakuan POC NASA terdiri atas 4 konsentrasi pupuk organik cair, yakni: (P0): tanpa perlakuan pupuk organik cair, (P1): perlakuan dengan konsentrasi $50 \mathrm{ml} / \mathrm{polybag}$, (P2): perlakuan dengan konsentrasi $100 \mathrm{ml} /$ polybag, dan (P3): perlakuan dengan konsentrasi $150 \mathrm{ml} /$ polybag. Data hasil pengamatan dianalisis dengan analisis sidik ragam ANOVA, apabila berbeda nyata maka dilanjutkan dengan Uji Beda Nyata terkecil (BNT) pada taraf 5\%. Hasil penelitian menunjukkan pengaruh nyata terhadap pertumbuhan dan hasil tanaman bawang merah varietas lokal Wamena yang terlihat pada parameter tinggi tanaman, jumlah daun dan bobot segar umbi tanaman dengan konsentrasi terbaik ditunjukkan oleh perlakuan P3 (150 ml/polybag).
\end{abstract}

Kata Kunci : bawang merah, NASA, pupuk organik cair, varietas lokal, wamena

\section{Pendahuluan}

Bawang merah termasuk komoditas sayuran berpotensi untuk dikembangkan guna meningkatkan pendapatan petani. Kemampuan produksi budidaya masih belum mampu memenuhi permintaan pasar dalam negeri yang terus meningkat. Konsumsi bawang merah penduduk Indonesia sejak tahun 1993-201 menunjukkan perkembangan yang fluktuatif namun relatif meningkat. Konsumsi rata-rata bawang merah untuk tahun 1993 adalah $1,33 \mathrm{~kg} / \mathrm{kapita} / \mathrm{tahun}$ dan pada tahun 2012 konsumsi bawang merah telah mencapai $2,764 \mathrm{~kg} / \mathrm{kapita} / \mathrm{tahun}$ (Dirjen Hortikultura 2013). Papua merupakan salah satu tempat penghasil Bawang merah di Indonesia.

Bawang merah (Allium cepa var. Agregatum L.) menjadi salah satu komoditas unggulan hortikultura yang berperan penting bagi konsumen untuk memenuhi kebutuhan sehari-hari. Bawang merah umumnya digunakan sebagai bahan rempah untuk masakan dan digunakan sebagai obat tradisional untuk berbagai penyakit. Produksi bawang merah masih rendah dan belum stabil. Oleh karena itu, dilakukan berbagai penelitian untuk dapat mengatasi hal tersebut, baik secara intensifikasi maupun ekstensifikasi (Nugrahini, 2013).

Upaya untuk meningkatkan produksi tanaman bawang merah antara lain dengan perbaikan sistem budidaya misalnya penerapan pertanian organik berkelanjutan, seperti pemanfaatan pupuk organik cair. Penggunaan pupuk organik cair pada tanah secara terus menerus berfungsi untuk meningkatkan kesuburan tanah. Pemberian pupuk dapat menambah unsur hara di dalam media tanam. Pemberian pupuk dapat berupa pupuk organik maupun anorganik.

Salah satu alternatif untuk mempertahankan dan meningkatkan hasil tanaman bawang merah adalah dengan pemberian pupuk organik cair. Pupuk organik cair tidak menimbulkan efek buruk bagi kesehatan tanaman karena bahan dasarnya alamiah, sehingga mudah diserap secara menyeluruh oleh tanaman. Pupuk organik cair kebanyakan diaplikasikan melalui daun atau disebut sebagai pupuk cair foliar yang mengandung hara makro dan mikro esensial $(\mathrm{N}$, $\mathrm{P}, \mathrm{K}, \mathrm{S}, \mathrm{Ca}, \mathrm{Mg}, \mathrm{B}, \mathrm{Mo}, \mathrm{Cu}, \mathrm{Fe}, \mathrm{Mn}$, dan bahan organik). Pupuk organik cair mempunyai beberapa manfaat diantaranya dapat mendorong dan meningkatkan pembentukan klorofil daun dan pembentukan bintil akar pada tanaman leguminosa sehingga meningkatkan kemampuan fotosintesis tanaman dan menyerap nitrogen dari udara (Yusuf, 2010). Selain itu, penggunaan POC dapat meningkatkan produksi tanaman bawang merah dan menjaga keseimbangan hara pada tanah. POC juga baik bagi lingkungan karena tidak menyebabkan pencemaran lingkungan serta menyediakan mikroorganisme tanah.

Pupuk organik cair adalah larutan dari hasil pembusukan bahan-bahan organik yang berasal dari sisa tanaman, kotoran hewan dan manusia yang kandungan unsur haranya lebih dari satu unsur. Kelebihan dari pupuk organik ini adalah mampu mengatasi defisiensi hara secara cepat, tidak bermasalah dalam pencucian hara, dan juga mampu menyediakan hara secara cepat. Jika dibandingkan dengan pupuk anorganik, pupuk organik cair umumnya 
tidak merusak tanah dan tanaman meskipun sudah digunakan sesering mungkin. Selain itu, pupuk ini juga memiliki bahan pengikat sehingga larutan pupuk yang diberikan ke permukaan tanah bisa langsung dimanfaatkan oleh tanaman (Hadisuwito, 2012).

Pupuk organik cair mengandung unsur hara makro dan unsur hara mikro yang dibutuhkan tanaman. Selain unsur hara, pupuk organik cair mengandung mikroorganisme yang tidak terdapat di dalam tanah misalnya Azotobacter sp, Azospinillum sp, Lactobacillus sp, Pseudomonas sp, mikroba pelarut phospat, dan mikroba selulotik (Purwati, 2018).

Salah satu pupuk organik cair yang diperdagangkan, yang siap diaplikasikan ke tanaman yaitu pupuk organik cair NASA. Kemasannya berupa botol yang diproduksi oleh PT Natural Nusantara Indonesia. Pupuk organik cair Nasa adalah salah satu jenis pupuk yang bisa diberikan ke daun dan tanah, mengandung unsur hara makro, mikro lengkap, dapat mengurangi penggunaan Urea, SP-36 dan $\mathrm{KCl}+12,5 \%-25 \%$. Kandungan unsur hara pupuk organik cair Nasa adalah N 0,12\%, P2O5 0,03\%, K 0,31\%, Ca 60,4 ppm, Mn 2,46 ppm, Fe 12,89 ppm, Cu 0,03 ppm, Mo 0.2 ppm (Anonim, 2005).

Pupuk organik cair (POC) merupakan pupuk organik dalam bentuk cair yang dapat digunakan untuk menambah nutrisi bagi tanaman. Penggunaan pupuk organik cair dapat mempengaruhi produksi tanaman bawang merah. Pupuk organik cair NASA pada konsentrasi $3 \mathrm{ml} / \mathrm{liter}$ dapat menghasilkan produksi umbi sebesar 9, $12 \mathrm{Mg} / \mathrm{Ha}$ (Nugrahini, 2013).

Penggunaan pupuk organik akan dapat meningkatkan hasil umbi tanaman bawang merah, sebab bahan organik tanah mempunyai pengaruh yang baik terhadap perkembangan mikro organisme dalam tanah dengan pemberian pupuk organik mampu meningkatkan aktivitas mikro organisme dalam merombak bahan organik menjadi unsur yang tersedia bagi tanaman. Hal ini dikarenakan, pupuk organik termasuk pupuk majemuk lengkap karena kandungan unsur haranya lebih dari satu unsur dan mengandung unsur mikro. Unsur hara dalam tanah tersedia dalam jumlah yang cukup, penyerapan unsur hara dalam jumlah yang cukup mampu meningkatkan proses fotosintesis barjalan cepat yang secara tidak langsung akan berpengaruh terhadap peningkatan pertumbuhan dan hasil tanaman bawang merah (Gardner dan Mitchell, 2001).

\section{Metodologi}

Penelitian ini dilaksanakan pada bulan Juni - Agustus 2018 di lahan percobaan STIPER Petra Baliem Wamena kemudian dilanjutkan di Laboratorium Agroteknologi STIPER Petra Baliem Wamena.

Alat yang digunakan dalam penelitian ini adalah peralatan tanam, alat tulis, penggaris, timbangan analitik, dan kamera. Sedangkan, bahan yang digunakan adalah air, benih bawang merah varietas lokal Wamena, pupuk kandang sapi sebagai pupuk dasar dan pupuk organik cair (POC) NASA.

Adapun prosedur pelaksanaan penelitian setelah alat dan bahan yang dibutuhkan tersedia adalah bawang merah yang diperoleh disortir berdasarkan ukuran dan tergolong sehat, Sebelum umbi bawang ditanam, terlebih dahulu diberikan perlakuan pemberian POC NASA pada masingmasing polybag sesuai dengan perlakuan yang telah ditetapkan. Adapun perlakuan POC NASA terdiri atas 4 konsentrasi pupuk organik cair, yakni:

- (P0): tanpa perlakuan pupuk organik cair,

- (P1): perlakuan dengan konsentrasi $50 \mathrm{ml} /$ polybag,

- (P2): perlakuan dengan konsentrasi 100 ml/polybag, dan

- (P3): perlakuan dengan konsentrasi $150 \mathrm{ml} /$ polybag.

Perlakuan diulang sebanyak 3 kali, sehingga terdapat 12 total perlakuan, dan masing-masing perlakuan terdiri dari 5 tanaman, sehingga terdapat 60 polybag dimana 3 polybag merupakan tanaman sampel untuk tiap perlakuan. Sehingga terdapat 36 polybag sebagai tanaman sampel.

Penanaman dilakukan dengan cara membuat lubang kecil pada media tanam yang telah diisi ke dalam polibag berukuran $3 \mathrm{~kg}$ dengan menggunakan penugal kecil. Umbi dipotong $1 / 3$ bagian, kemudian dimasukkan ke dalam lubang yang telah dibuat sebelumnya. Setelah itu permukaan tanah ditutup sedikit hingga bibit bawang merah sedikit terbenam dalam media tanam.

Pengamatan yang dilakukan pada penelitian ini adalah tinggi tanaman $(\mathrm{cm})$, jumlah daun (helai). Kedua parameter ini diamati pada saat tanaman berumur 1, 3 dan 5 MST. Selanjutnya, parameter bobot segar daun (gr), bobot kering daun (gr) yang diamati pada saat tanaman berumur 9 MST. Kemudian, parameter bobot segar umbi (gr) yang diamati pada tanaman berumur 12 MST.

Data hasil pengamatan dianalisis dengan analisis sidik ragam ANOVA, apabila berbeda nyata maka dilanjutkan dengan Uji Beda Nyata terkecil (BNT) pada taraf 5\%.

\section{Hasil}

Hasil analisis ragam untuk parameter tanaman yang diamati menunjukkan pengaruh yang bervariasi. Parameter tinggi tanaman pada pengamatan 1, 3 dan 5 minggu setelah perlakuan (MSP) menunjukkan respon yang berbeda-beda. Hasil penelitian menunjukkan pengaruh nyata pada pengamatan 1 dan 5 minggu setelah perlakuan (MSP) dibandingkan dengan tinggi tanaman pada pengamatan 3 minggu setelah perlakuan (MSP) yang menunjukkan tidak ada pengaruh nyata dari pemberian POC. Hasil penelitian tinggi tanaman bawang merah dapat dilihat pada tabel 1.

Hasil penelitian pengamatan parameter tinggi tanaman pada 1 MSP menunjukkan pengaruh yang sangat nyata pada perlakuan P3 (150 ml/polybag) dengan rerata sebesar 25,97 $\mathrm{cm}$ dan tidak berpengaruh nyata terhadap perlakuan P2 (100 $\mathrm{ml} /$ polybag). Sedangkan pada pengamatan 5 minggu setelah perlakuan (MSP), perlakuan P0 (kontrol/tanpa POC) menunjukkan rerata tertinggi dibandingkan perlakuan dengan pemberian POC.

Hal ini menunjukkan bahwa pemberian POC diawal pertumbuhan memberikan adanya penambahan kebutuhan hara bagi tanaman dalam meningkatkan pertumbuhan tanaman. Hal ini diketahui POC merupakan kelompok pupuk organik yang diketahui mengandung bahan 
pembenah tanah yang paling baik dan alami daripada bahan pembenah buatan.

Tabel 1. Rerata Tinggi Tanaman Bawang Merah Varietas Lokal Wamena $(\mathrm{cm})$

\begin{tabular}{cccc}
\hline \multirow{2}{*}{ Perlakuan } & \multicolumn{3}{c}{ Umur Pengamatan (cm/MSP) } \\
\cline { 2 - 4 } & 1 & 3 & 5 \\
\hline P0 & $22,86 \mathrm{ab}$ & $53,15 \mathrm{a}$ & $74,93 \mathrm{a}$ \\
P1 & $19,69 \mathrm{~b}$ & $53,83 \mathrm{a}$ & $70,83 \mathrm{ab}$ \\
P2 & $25,15 \mathrm{a}$ & $52,71 \mathrm{a}$ & $72,92 \mathrm{ab}$ \\
P3 & $25,97 \mathrm{a}$ & $50,17 \mathrm{a}$ & $53,15 \mathrm{~b}$ \\
\hline Koefisien & $1,61 \%$ & $1,23 \%$ & $2,02 \%$ \\
\hline Keragaman (KK) & $* *$ & tn & $* *$ \\
\hline Uji F & $5,00 \%$ & - & $18,21 \%$
\end{tabular}

Ket. : Angka pada kolom yang diikuti huruf yang berbeda pada faktor perlakuan yang sama menunjukkan pengaruh nyata pada uji BNT $5 \%$; PO: 0

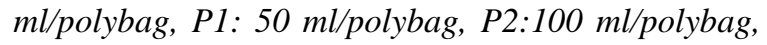
P3:150 ml/polybag.

Pada umumnya pupuk organik mengandung unsur hara makro N, P, K rendah, tetapi mengandung hara mikro dalam jumlah cukup yang sangat diperlukan pertumbuhan tanaman. Sebagai bahan pembenah tanah, pupuk organik mencegah terjadinya erosi, pergerakan permukaan tanah dan retakan tanah, dan mempertahankan kelengasan tanah (Sutanto, 2005; Tambunan, 2014). Wu et al. (2005) menambahkan penggunaan pupuk hayati tidak hanya meningkatkan kadar unsur hara pada tanaman seperti nitrogen $(\mathrm{N})$, fosfor $(\mathrm{P})$, dan kalium $(\mathrm{K})$, tetapi juga menjaga kandungan senyawa organik dan total $\mathrm{N}$ dalam tanah.

Dibandingkan dengan pengamatan 5 (MSP), meskipun berpengaruh nyata tetapi hal ini ditunjukkan oleh perlakuan tanpa pemberian POC (P0). Hal ini menunjukkan bahwa, pada saat memasuki fase generatif tanaman, pengaruh perlakuan pemberian POC tidak berpengaruh terhadap pertumbuhan tanaman. Hal ini dipengaruhi oleh adanya penambahan pupuk kandang yang merupakan bahan organik yang ditambahkan sebagai pupuk dasar. Pemberian bahan organik pada tanah berperan penting dalam memperbaiki struktur tanah sehingga aerasi udara dan pergerakan air lancar, dengan demikian dapat menambah daya serap air dalam tanah dan mampu meningkatkan pertumbuhan dan produksi tanaman (Widawati et al. 2002) tetapi dalam hal ini pemberian pupuk organik dan pupuk hayati tidak nyata memberikan pengaruh terhadap pertumbuhan tanaman akan tetapi pemberian pupuk organik dapat memberikan beberapa keuntungan, seperti struktur tanah yang lebih baik, meningkatkan hara tersedia bagi tanaman, dan meningkatkan populasi dan aktivitas mikroba tanah (Suliasih et al. 2010).

Selanjutnya, Tabel 2 menunjukkan hasil pengamatan terhadap parameter jumlah daun tanaman bawang merah varietas lokal Wamena, terlihat berpengaruh nyata pada perlakuan P2 (100 ml/polybag) pengamatan 2 minggu setelah perlakuan (MSP), dengan jumlah rerata sebesar
32,07 helai dan berbeda sangat nyata dengan tanaman P0 (kontrol/tanpa POC).

Hasil pengamatan parameter jumlah daun tanaman menunjukkan pengaruh sangat nyata pada pengamatan 1, 3 dan 5 minggu setelah perlakuan (MSP). Rerata jumlah daun tertinggi ada pengamatan 1 minggu setelah perlakuan (MSP) ditunjukkan oleh perlakuan P2 (100 ml/polybag), yakni sebesar 32,07 helai dan tidak berbeda nyata dengan perlakuan P3 (150 ml/polybag). Selanjutnya, rerata jumlah daun tertinggi pada pengamatan 3 dan 5 minggu setelah perlakuan (MSP) ditunjukkan oleh perlakuan yang sama, yaitu perlakuan P3 (150 ml/polybag) dengan jumlah rerata pada pengamatan 3 dan 5 minggu setelah perlakuan (MSP) adalah sama, yakni 92,93 helai.

Tabel 2. Rerata Jumlah Daun Tanaman Bawang Merah Varietas Lokal Wamena (helai)

\begin{tabular}{|c|c|c|c|}
\hline \multirow{2}{*}{ Perlakuan } & \multicolumn{3}{|c|}{ Umur Pengamatan (Helai/MSP) } \\
\hline & 1 & 3 & 5 \\
\hline $\mathrm{P} 0$ & $13,56 \mathrm{ab}$ & $40,65 \mathrm{~b}$ & $54,72 \mathrm{~b}$ \\
\hline $\mathrm{P} 1$ & $14,19 \mathrm{ab}$ & $38,66 \mathrm{~b}$ & $56,24 \mathrm{~b}$ \\
\hline $\mathrm{P} 2$ & $32,07 \mathrm{a}$ & $51,30 \mathrm{ab}$ & $80,67 \mathrm{ab}$ \\
\hline P3 & $31,14 \mathrm{a}$ & $93,92 \mathrm{a}$ & $93,92 \mathrm{a}$ \\
\hline $\begin{array}{c}\text { Koefisien } \\
\text { Keragaman (KK) }\end{array}$ & $1,51 \%$ & $1,31 \%$ & $2,61 \%$ \\
\hline Uji F & $* *$ & $* *$ & $* *$ \\
\hline BNT $5 \%$ & $4,57 \%$ & $7,77 \%$ & $24,81 \%$ \\
\hline $\begin{aligned} \text { Ket. : Angka pada } \\
\text { pada faktor } \\
\text { pengaruh } \\
\text { ml/polybag, } \\
\\
\text { P3:150 ml/po }\end{aligned}$ & $\begin{array}{l}\text { om yang } \\
\text { erlakuan } \\
\text { a pada } \\
50 \mathrm{ml} / \mathrm{pc} \\
\text { bag }\end{array}$ & $\begin{array}{l}\text { kuti huruf } \\
\text { ng sama } \\
\text { BNT } 5 \\
\text { bag, P2:1 }\end{array}$ & $\begin{array}{l}\text { ing berbec } \\
\text { nenunjukkc } \\
\% \text {; PO: } \\
\mathrm{ml} / \text { polybc }\end{array}$ \\
\hline
\end{tabular}

Pertumbuhan tanaman bawang merah terlihat baik pada pengamatan jumlah daun tanaman. Hasil penelitian menunjukkan pemberian POC dengan dosis 100 dan 150 $\mathrm{ml} /$ polybag menunjukkan rerata tertinggi pada tiap umur pengamatan (Tabel 2). Hal ini menunjukkan tanaman merespon dengan cepat pemberian POC, baik pada awal pertumbuhan maupun dalam siklus fase vegetatif tanaman. Ini menunjukkan bahwa ketersediaan hara tanaman opptimal melalui pemberian POC, sehingga mampu menunjang pertumbuhan tanaman (Rahman, 2011) atau dapat dikatakan bahwa pemberian pupuk cair $150 \mathrm{ml} /$ polybag (P3) mampu memberi kecukupan hara bagi tanaman. Ketersedian hara yang cuku bagi tanaman diketahui menunjang proses pembelahan, pembesaran dan pemanjangan sel dengan cepat sehingga organ tumbuh tanaman tumbuh dengan cepat (Palimbungan \& Hamzah, 2006).

Pertumbuhan daun tanaman dalam jumlah banyak diketahui akan berpengaruh pada proses fotosintesis tanaman. Peningkatan proses fotosintesis berpengaruh pada jumlah klorofil yang dihasilkan dalam pembentukan umbi bawang merah. Meskipun pengamatan, bobot segar dan bobot kering daun tanaman tidak menunjukkan adanya pengaruh nyata pemberian POC. Hal ini diduga karena unsur hara yang terdapat pada media tanam belum dapat diserap secara optimal oleh tanaman pada awal 
pertumbuhan. Karena tanaman bawang merah memiliki cadangan makanan sendiri untuk membantu proses tumbuhnya pada awal masa pertumbuhan. Hal ini sesuai dengan pernyataan Sutedjo (2001) yang menyatakan bahwa kemampuan tanaman menyerap unsur hara selama pertumbuhan dan perkembangannya (terutama dalam hal pengambilan atau penyerapan) adalah tidak sama.

Tabel 3 menunjukkan hasil penelitian parameter bobot segar dan bobot kering daun tanaman bawang merah varietas lokal Wamena terhadap pemberian POC pada pengamatan 9 minggu setelah perlakuan (MSP). Hasil penelitian menunjukkan tidak adanya pengaruh nyata pemberian POC. Diketahui bahwa, bobot segar dan bobot kering daun tanaman berkaitan dengan kandungan air dalam daun tanaman. Ini menunjukkan bahwa kandungan air dalam daun tanaman dapat dikatakan rendah. Namun, hal ini tidak menunjukkan adanya pengaruh terhadap bobot segar umbi produksi yang diketahui pemberian POC memberikan pengaruh nyata.

Tabel 3. Rerata Bobot Segar Daun dan Bobot Kering Daun Tanaman Bawang Merah Varietas Lokal Wamena (gr)

\begin{tabular}{ccc}
\hline \multirow{2}{*}{ Perlakuan } & \multicolumn{2}{c}{ Umur Pengamatan 9 (MSP) } \\
\cline { 2 - 3 } & $\begin{array}{c}\text { Bobot Segar } \\
\text { Daun }(\mathrm{gr})\end{array}$ & $\begin{array}{c}\text { Bobot Kering } \\
\text { Daun }(\mathrm{gr})\end{array}$ \\
\hline P0 & $5,09 \mathrm{a}$ & $2,10 \mathrm{a}$ \\
P1 & $4,94 \mathrm{a}$ & $1,75 \mathrm{a}$ \\
P2 & $3,93 \mathrm{a}$ & $2,00 \mathrm{a}$ \\
P3 & $4,38 \mathrm{a}$ & $1,84 \mathrm{a}$ \\
\hline
\end{tabular}

\begin{tabular}{ccc}
\hline $\begin{array}{c}\text { Koefisien } \\
\text { Keragaman (KK) }\end{array}$ & - & - \\
\hline Uji F & tn & tn \\
\hline BNT 5 \% & - & - \\
\hline Ket. : Angka pada kolom yang diikuti huruf yang sama pada \\
faktor perlakuan yang sama menunjukkan pengaruh \\
tidak nyata pada uji BNT $5 \% ;$ P0: O ml/polybag, P1: \\
$\begin{array}{l}\text { 50 ml/polybag, } \\
\text { ml/polybag. }\end{array}$
\end{tabular}

Tabel 4 menunjukkan hasil penelitian terhadap parameter bobot segar umbi produksi tanaman bawang merah varietas lokal Wamena yang menunjukkan pengaruh sangat nyata, dimana rerata tertinggi ditunjukkan oleh perlakuan P3 (150 ml/polybag), yakni sebesar 22,11 gr. Hasil penelitian menunjukkan umbi segar yang dihasilkan sejalan dengan jumlah daun yang banyak terbentuk (Tabel 4). Bobot segar umbi berkaitan dengan jumlah asimilat yang terbentuk dari hasil fotosintesis tanaman. Menurut Rahman (2011) sebagian besar berat segar tanaman dipengaruhi oleh kandungan air dalam tubuh tanaman. Selanjutnya dikatakan oleh Gardner et. al. (1985) berat segar umumnya berfluktuasi, tergantung pada kelembaban tanaman. Hal ini yang menjadi pengaruh bagi umbi tanaman yang dihasilkan.
Tabel 4. Rerata Bobot Segar Umbi Bawang Merah Varietas Lokal Wamena (gr) Pengamatan 12 MST

\begin{tabular}{cc}
\hline Perlakuan & Rerata $(\mathrm{gr})$ \\
\hline P0 & $16,91 \mathrm{~b}$ \\
P1 & $11,98 \mathrm{~b}$ \\
P2 & $18,95 \mathrm{ab}$ \\
P3 & $22,11 \mathrm{a}$ \\
\hline Koefisien Keragaman & $6,57 \%$ \\
(KK) & $* *$ \\
\hline Uji F & 0,05 \\
\hline BNT 5 \%
\end{tabular}

Ket. : Angka pada kolom yang sama yang diikuti huruf yang berbeda pada faktor perlakuan yang sama menunjukkan pengaruh nyata pada uji BNT 5 \%; P0: 0 ml/Polybag, P1: $50 \mathrm{ml} /$ polybag, $\quad$ P2:100 $\mathrm{ml} /$ polybag, P3:150 $\mathrm{ml} /$ polybag.

Kualitas hidup tanaman diketahui sangat bergantung dari ketercukupan hara dari lingkungannya. Selain ditentukan oleh kemampuan tanaman dalam menyerap, perolehan hara juga tergantung dari tingkat ketersediaan hara di tanah. Tingkat kebutuhan hara antar tanamannya pun berbeda-beda (Fitter dan Hay, 1992). Pembentukan umbi tanaman bawang merah diduga berpengaruh dari pembentukan akar. Salisbury dan Ross (1985) menegaskan bahwa bentuk perakaran lebih banyak dikontrol oleh faktor genetik daripada faktor lingkungannya, walaupun lingkungan juga menentukan pembentukan akarnya. Perkembangan sistem perakaran dipengaruhi oleh kondisi substrat atau tanah sebagai media tumbuh tanaman. Banyaknya akar pada tanaman bawang merah diduga berpengaruh dari bentuk dan jumlah umbi tanaman. Hal ini berkaitan dengan pendistribusian mineral dalam tubuh tanaman untuk membentuk organ tanaman. Hall (1976) menyatakan bahwa akar mampu berkembang dalam merespons terhadap distribusi mineral dan air tanah.

\section{Kesimpulan}

Pemberian POC berpengaruh nyata terhadap pertumbuhan dan hasil tanaman bawang merah varietas lokal Wamena terbaik terlihat pada parameter tinggi tanaman, jumlah daun dan bobot segar umbi tanaman dengan konsentrasi terbaik ditunjukkan oleh perlakuan P3 (150 ml/polybag).

\section{Daftar Pustaka}

Anonim, 2005. http://www.produk natural.com/artikel/kandungan-pocnasa/ diakses tanggal 25 April 2018.

Dirjen Tanaman Pangan dan Hortikultura. 2013. Data Susenas. Departemen Pertanian. Jakarta.

Fitter, A. H. dan Hay, R.K.M. 1992. Fisiologi Lingkungan Tanaman, Yogyakarta: Gadjah Mada University Press

Gardner, F. P., R. B. Pearce dan R. L. Michell. 1985. Fisiologi Tanaman Budidaya. Susilo, H. dan Subiyanto (Penerjemah). UI Press: Jakarta. 
Gardner, F. P., R. B. Pearce dan R. L. Michell. 2001. Fisiologi tanaman budidaya. Jakarta: Universitas Indonesia Press.

Hall, M. A. 1976. Plant Structure, Function and Adaptation. The Macmillan Press, London.

Hadisuwito, S. 2012. Membuat Pupuk Organik Cair. Agromedia Pustaka. Jakarta.

Nugrahini, T. 2013. Respon tanaman bawang merah (Allium ascalonicum L.) varietas tuk tuk terhadap pengaturan jarak tanam dan konsentrasi pupuk organik cair NASA. Jurnal Ziraa'ah. 36(1): 60-65.

Palimbungan N., R. Dan Hamzah F. 2006. Pengaruh Ekstrak Daun lamptoro Sebagai Pupuk Organik Cair Terhadap Pertumbuhan dan Produksi Tanaman Sawi. Jurnal Agrisistem, 2(2): $96-101$.

Purwati E. 2018. Pengaruh Media Tanam dan Pupuk Organik Cair Terhadap Pertumbuhan dan Produksi Bawang Merah (Allium ascalonicum L.). Skripsi. Fakultas Pertanian, Universitas Lampung. Bandar Lampung.

Rahman A. Dan Lasiwua C. D. 2011. Aplikasi Pupuk Organik Cair Terhadap Pertumbuhan dan Produksi Tanaman Sawi. Jurnal Agrisitem, $7: 1$.

Salisbury F.B and Ross, C.W. 1995. Plant Physiology. 1985. 3rd Ed. Wardworth Publ. Comp. Belmont. California

Suliasih, S, Widati \& Muharam, A. 2010. Aplikasi pupuk organik dan bakteri pelarut fosfat untuk meningkatkan pertumbuhan tanaman tomat dan aktivitas mikrob tanah. J. Hort., 20(30): 241-6.

Sutanto, R. 2005. Pertanian Organik. Kanisius. Jakarta.

Sutedjo, M. M., 2001. Pupuk dan Cara Pemupukan. Penerbit Rineka Cipta. Jakarta.

Tambunan A. W., Sipayung R., dan Sitepu E. F. 2014. Pertumbuhan dan Produksi Bawang Merah (Allium ascalonicum L.) dengan Pemberian Pupuk Hayati pada Berbagai Media Tanam. Jurnal Online Agroekoteknologi, 2(2): $825-836$.

Widawati, S, Suliasih \& Syaifudin 2002, Pengaruh introduksi kompos plus terhadap produksi bobot kering daun kumis kucing (Orthosiphon aristatus $\mathrm{Bl}$. Miq) pada tiga macam media tanah. J. Biol. Indonesia, 3(3): $245-53$

Wu, SC, Cao, ZH, Cheung, KC \& Wong, MH 2005, 'Effects of biofertilizer containing $\mathrm{N}$-fixer, $\mathrm{P}$ and $\mathrm{K}$ solubilizers and $\mathrm{AM}$ fungi on maize gowth: A greenhouse trial', Geoderma, vol. 125, pp. 155-66.

Yusuf, T., 2010. Pemupukan dan Penyemprotan Lewat Daun. Tohari Yusuf's. Pertanian Blog. http://tohariyusuf.wordpress.com/. 